\title{
DUKUNGAN KELUARGA TERHADAP SELF CARE PADA LANSIA DENGAN DIABETES MELITUS TIPE 2
}

\author{
Hera Heriyanti ${ }^{1)}$, Sigit Mulyono ${ }^{2)}$, Lily Herlina ${ }^{3)}$ \\ 1. Mahasiwa Program Magister Keperawatan Fakultas Keperawatan Muhammadiyah Jakarta \\ 2. Dosen Program Magister Keperawatan Fakultas Keperawatan Muhammadiyah Jakarta \\ email : heraheriyanti@gmail.com
}

\begin{abstract}
Elderly is a population of risk that has limitations caused by the deterioration of various systems. Elderly accompanied by chronic DM disease and lack of support system results in elderly with DM entering the vulnerable group. Therefore, the elderly with DM need help to support their quality and satisfaction of life. The support is very much needed especially from the family, because the family is an element that is very closely related to the elderly. For this reason, it is expected that the family can support in the form of attention, can receive, give love so that the elderly are able to do selfcare. Objective: this study aims to determine the relationship of family support for self-care in the elderly with type 2 diabetes. Method: quantitative research with descriptive observational research design with cross sectional approach. The population in this study were all elderly with DM type 2 in the work area of PuskesmasWara Selatan of Palopo City as many as 153 people. The sampling technique used is nonprobability sampling with a sample of 121 people. Data collection uses questionnaire respondent characteristics, family support, and self-care. Results: From the analysis it was found that the variable most related to self-care was emotional support with the value Exp (B) $=10.875$. Conclusion: It is hoped that health workers in the health center of South Wara will further promote health promotion regarding the importance of family support to improve self-care and health status of the elderly with DM.
\end{abstract}

Keywords: DM type 2, Family Support, Self-Care

\section{PENDAHULUAN}

Lansia (lanjut usia) merupakan tahap akhir perkembangan pada daur kehidupan manusia yang merupakan suatu proses alami yang tidak dapat dihindari, berjalan terus menerus dan berkesinambungan. Selanjutnya akan menyebabkan perubahan anatomis, fisiologis dan biokimia pada tubuh sehingga akan mempengaruhi fungsi dan kemampuan tubuh keseluruhan. Lansia merupakan kelompok umur dimana terjadi penurunan kondisi fisik, biologis dan kondisi sosial (Sunaryo et al., 2016). Lansia merupakan populasi resiko yang memiliki keterbatsan yang diakibatkan oleh kemunduran berbagai sistem. Lansia yang disertai dengan penyakit kronik salah satunya DM masuk pada kelompok rentan(Allender, Rector \& Warmer, 2014).

Diabetes Melitus adalah ketidakmampuan tubuh untuk melakukan metabolisme karbohidrat, lemak dan protein yang mengarah ke hiperglikemia (kadar glukosa darah tinggi) yang merupakan penyakit kronis progresif. (Black \& Hawks, 2014).Menurut data WHO jumlah kasus penyakit diabetes mellitus pada tahun 2015 yaitu sebesar 415 juta jiwa. Pada tahun 2040 diperkirakan jumlahnya akanmenjadi 642 juta (Atlas, 2015). Hasil riset kesehatan dasar (Riskesdas), pada tahun tahun 2013 melaporkan bahwa terdapat $6,9 \%$ penderita DM sedangkan pada tahun 2018 sebesar 8,5 $\%$. Dari data tersebut terjadi peningkatan prevalensi DM 1,6 \% (Riskesdas 2018).

Peningkatan jumlah DM paling besar di Indonesia berada di Provinsi Sulawesi Selatan yaitu sebesar 2,6\%. Kasus diabetes berkisar antara $1,0 \%$ sampai $6,1 \%$ yang tersebar di 25 kabupatenkota. Kasus DM paling banyak ditemukan di kabupaten/kota Tanah Toraja $(6,1 \%)$, Makassar $(5,3 \%)$, dan Luwu $(5,2 \%)$. 
Diabetes di Sulawesi Selatan paling banyak ditemukan pada usia 55-74 (13,4\%), penyakit ini sudah ditemukan pada usia 15-24 (2\%). Dari segi jenis kelamin paling banyak pada perempuan $(3,6 \%)$, dan terbanyak ditemukan di daerah perkotaan $(2,4 \%)$. (Riskesdas, 2013).

Menurut Perkeni (Perhimpunan Endokrinologi Indonesia) ada lima pilar penanganan DM, dengan tujuannya adalah mengontrol kadar gula darah sehingga dapat menurunkan angka kesakitan dan kematian akibat komplikasi serta meningkatkan kualitas hidup pasien DM meliputi : edukasi, diet nutrisi, aktivitas fisik (olahraga), obat-obatan, dan monitor kadar gula darah (PERKENI). Maka dari itu untuk mencapai lima pilar tersebut individu sebaiknya mampu untuk melakukan self-care.

Self care merupakan kebutuhan manusia terhadap kondisi dan perawatan diri sendiri yang dengan menjalankan perencanaan dan pelaksanaan prinsip perawatan dengan baik. Upaya tersebut dilakukan secara terus menerus untuk mempertahankan kehidupan serta penyembuhan dari penyakit untuk mengatasi komplikasi yang akan timbul. Oleh karena itu keluarga dapat terlibat dalam proses ini dalam memberikan informasi terhadap klien dalam membantu mereka untuk melakukan self care yang efektif (BORJI et al, 2017).

Dalam konteks ini, keluarga memiliki peranan penting dalam pengobatan dan perawatan pasien dengan DM tipe 2, terutama mereka yang secara luas terlibat dalam kehidupan sehari-hari pasien. Keluarga yang baik dapat mendukung kepatuhan terhadap pengobatan melalui perubahan gaya hidup, perubahan tersebut tidak hanya mempengaruhi pasien diabetes itu sendiri tetapi juga keluarganya. Hal ini terjadi karena perubahan dalam kebiasaan makan, aktifitas fisik, frekuensi kunjungan ke pelayanan kesehatan, serta perawatan kaki (Santos AL \& Marcon SS, 2014)

Dukungan keluarga merupakan sikap, tindakan penerimaan keluarga terhadap anggota keluarganya, berupa dukungan emosional, dukungan informasi, dukungan penghargaan serta dukungan instrumental. Keluarga merupakan salah satu support system dalam pemberian pelayanan keperawatan dirumah dan penatalaksanaan klien diabetes melitus (Friedman, 2010).

Hal ini didukung oleh penelitian Arief Yanto dan Dewi Setyawati (2017) penelitian menunjukkan bahwa dukungan keluarga pasien dengan diabetes tipe 2 memiliki nilai rata-rata 61,52 dengan kategori dukungan keluarga tinggi sebanyak 70 responden $(72,9 \%)$ dan tingkat rendah sebanyak 26 responden $(27,1 \%)$. Dengan dukungan keluarga yang baik akan mendukung pelaksanaan program terapi sehingga akan menurunkan kadar gula darah (Arief Yanto, 2017).

Berdasarkan latar belakang diatas, peneliti tertarik untuk melakukan penelitian tentang sejauh mana dukungan keluarga terhadap selfcare pada lansia dengan DM tipe 2 di Wilayah Kerja Puskesmas Wara Selatan Kota Palopo.

\section{METODE}

Penelitian ini menggunakan desain penelitian deskriptif observasional dengan menggunakan metode pendekatan cross sectional. Jumlah sampel pada penelitian ini adalah 121 responden. Teknik pengambilan sampel pada penelitian ini adalah teknik nonprobability sampling dan dipilih dengan menggunakan purposive sampling. Alat pengumpul data pada penelitian ini adalah berupa kuesioner tentang dukungan keluarga dan aktifitas perawatan mandiri yang sudah di uji validitas.

Untuk prosedur teknis Peneliti mengikuti jadwal prolanis serta kunjungan rumah untuk proses penyebaran kuesioner nantinya. Dimana kegiatan tersebut dilaksanakan 1-2 kali dalam seminggu setiap posyandu di wilayah kerja puskesmas wara selatan terdapat 4 posyandu lansia. Kegiatan kunjungan rumah dilakukan apabila kegiatan diposyandu lansia telah selesai, dalam hal ini kegiatan tersebut dilaksanakan apabila lansia tidak dapat berkunjung langsung ke posyandu lansia. 


\section{HASIL}

\section{Tabel 1 Distribusi Frekuensi Karakteristik DM Tipe 2}

\begin{tabular}{|c|c|c|}
\hline Karakteristik & $\mathbf{f}$ & $\%$ \\
\hline $\begin{array}{l}\text { Umur } \\
\text { Usia Pertengahan } \\
\text { (45-59 tahun) } \\
\text { Lanjut Usia } \\
\text { (60-74 tahun) }\end{array}$ & 75 & 62,0 \\
\hline $\begin{array}{c}\text { Jenis Kelamin } \\
\text { Laki-laki } \\
\text { Perempuan }\end{array}$ & $\begin{array}{l}49 \\
72\end{array}$ & $\begin{array}{l}40,5 \\
59,5\end{array}$ \\
\hline $\begin{array}{c}\text { Pendidikan } \\
\text { Rendah } \\
\text { Tinggi }\end{array}$ & $\begin{array}{l}49 \\
72\end{array}$ & $\begin{array}{r}40,5 \\
59,5\end{array}$ \\
\hline $\begin{array}{l}\text { Pendapatan } \\
\text { Rendah } \\
\text { Tinggi }\end{array}$ & $\begin{array}{l}85 \\
36\end{array}$ & $\begin{array}{c}70,2 \\
29,8\end{array}$ \\
\hline $\begin{array}{l}\text { Lama Menderita } \\
1-4 \text { tahun } \\
>4 \text { tahunm }\end{array}$ & $\begin{array}{l}68 \\
53\end{array}$ & $\begin{array}{l}56,2 \\
43,8\end{array}$ \\
\hline
\end{tabular}

Berdasarkan tabel diatas menunjukkan bahwa responden sebagian besar memiliki umur dengan usia pertengahan (45-59 tahun) yaitu 75 responden $(62,0 \%)$. Responden dengan Jenis kelamin perempuan sebanyak 72 responden $(59,5 \%)$,sebagan besar responden dengan pendidikan tinggi 72 responden (59,5\%). Responden dengan pendapatan dalam kategori rendah sebanyak 85 responden $(70,2 \%)$. Responden dengan lama menderita $1-4$ tahun sebanyak 68 responden $(56,2 \%)$.

Tabel 2 Hubungan dukungan emosional, penghargaan, informasi, instrumental terhadap selfcare

\begin{tabular}{|c|c|c|c|c|c|c|c|c|}
\hline \multirow{3}{*}{ Variabel } & \multicolumn{6}{|c|}{ Self Care } & \multirow{3}{*}{$p$ value } & \multirow{3}{*}{ Ods Ratic } \\
\hline & \multicolumn{2}{|c|}{ Kurang } & \multicolumn{2}{|c|}{ Baik } & \multicolumn{2}{|c|}{ Total } & & \\
\hline & $\mathrm{F}$ & $\%$ & $\mathrm{~F}$ & $\%$ & $\mathrm{~F}$ & $\%$ & & \\
\hline \multicolumn{9}{|c|}{ Dukungan Emosional } \\
\hline Kurang & 46 & 86,8 & 7 & 13,2 & 53 & 100 & \multirow[t]{2}{*}{0,001} & \multirow[t]{2}{*}{19,714} \\
\hline Baik & 17 & 25,0 & 51 & 75,0 & 68 & 100 & & \\
\hline \multicolumn{9}{|c|}{ Dukungan Penghargaan } \\
\hline Kurang & 47 & 74,6 & 16 & 25,4 & 63 & 100 & \multirow[t]{2}{*}{0,001} & \multirow[t]{2}{*}{7,711} \\
\hline Baik & 16 & 27,6 & 42 & 72,4 & 58 & 100 & & \\
\hline \multicolumn{9}{|c|}{ Dukungan Informasi } \\
\hline Kurang & 48 & 76,2 & 15 & 23,8 & 63 & 100 & \multirow[t]{2}{*}{0,001} & \multirow[t]{2}{*}{9,173} \\
\hline Baik & 15 & 25,9 & 43 & 74,1 & 58 & 100 & & \\
\hline \multicolumn{9}{|c|}{ Dukungan Instrumental } \\
\hline Kurang & 47 & 78,3 & 13 & 21,7 & 60 & 100 & \multirow[t]{2}{*}{0,001} & \multirow[t]{2}{*}{10,168} \\
\hline Baik & 16 & 26,2 & 45 & 73,8 & 61 & 100 & & \\
\hline
\end{tabular}


Hasil uji bivariat menunjukkan adanya hubungan yang bermakna antara dukungan emosional,dukungan instrumental, dukungan penghargaan, dukungan informasi terhadap self-care pada lansia dengan DM tipe 2 dengan hasil uji chi squarediperoleh $p$ value $=0,001$ $(\mathrm{p}<0,05)$.

Tabel 3 Hasil Analisis Regresi Logistik Ganda variabel dukungan emosional, dukungan penghargaan, dukungan emosional, dukungan informasi terhadap self-care

\begin{tabular}{lcccccc}
\hline $\begin{array}{l}\text { Dukungan } \\
\text { Keluarga }\end{array}$ & $\mathrm{B}$ & $\mathrm{SE}$ & P Value & Exp.(B) & \multicolumn{2}{c}{ 95\% C.I.for EXP(B) } \\
\cline { 5 - 7 } & & & & & Lower & Upper \\
\hline $\begin{array}{l}\text { Dukungan } \\
\text { Instrumental }\end{array}$ & 1,548 & 0,524 & 0,003 & 4,702 & 1,685 & 13,121 \\
\hline $\begin{array}{l}\text { Dukungan } \\
\text { emosional }\end{array}$ & 2,386 & 0,545 & 0,001 & 10,875 & 3,737 & 31,646 \\
\hline $\begin{array}{l}\text { Dukungan } \\
\text { informasi }\end{array}$ & 1,237 & 0,523 & 0,018 & 3,445 & 1,236 & 9,601 \\
\hline
\end{tabular}

Berdasarkan tabel 3 hasil analisis regresi logistik ganda, pada penelitian ini menggunakan 4 langkah untuk sampai pada hasil akhir. Pada step ke 4 variabel dukungan informasi dimasukkan kembali kedalam permodelan karena perubahan OR dari variabel dukungan instrumental dan dukungan emosional lebih dari $10 \%$ yaitu $27 \%$, sehingga dari step tersebut dapat diambil kesimpulan bahwa semakin besar nilai Exp (B) atau OR maka variabel tersebut semakin kuat hubungannya dengan variabel independen. Sehingga dukungan emosional memiliki nilai $\operatorname{Exp}(B)$ lebih tinggi yaitu 10,875 maka dapat disimpulkan bahwa dukungan emosional memiliki hubungan yang kuat terhadap self-care pada lansia dengan DM, dari model diatas dapat dijelaskan bahwa lansia yang mendapatkan dukungan emosional yang baik mempunyai peluang 10,875 kali dapat melakukan self care dengan baik.

\section{PEMBAHASAN}

\section{a. Hubungan Dukungan Emosional terhadap self-care}

Hasil uji statistik pada hubungan antara dukungan emosional dengan self-care menunjukkan terdapat hubungan yang erat dan $\operatorname{postif}(p$ value: 0,001$)$ antara dukungan emosional dengan self-care. Dukungan emosional berupa ekspresi empati, perhatian, pemberian semangat, kehangatan pribadi, cinta atau bantuan emosional. Dengan semua tingkah laku yang mendorong perasaan nyaman dan mengarahkan individu untuk percaya bahwa ia dipuji, dihormati, dicintai dan bahwa orang lain bersedia memberikan perhatian (Sarafino,2011).

\section{b. Hubungan Dukungan Informasi terhadap self-care}

Hasil uji statistik pada hubungan antara dukungan informasi dengan self-care menunjukkan terdapat hubungan yang erat dan postif ( $p$ value: 0,001$)$ antara dukungan emosional dengan self-care.Dukungan informasi keluarga merupakan suatu dukungan atau bantuan yang diberikan keluarga dalam bentuk memberikan saran atau masukan, nasehat atau arahan dan memberikan informasi-informasi penting yang dibutuhkan lansia dengan DM dalam upaya meningkatkan status kesehatannya (Bomar, 2004).

\section{c. Hubungan Dukungan Penghargaan terhadap self-care}

Hasil uji statistik pada hubungan antara dukungan penghargaan dengan selfcare menunjukkan terdapat hubungan yang erat dan postif ( $p$ value: 0,001$)$ antara dukungan emosional dengan selfcare.Keluarga memberikan dukungan penghargaan lewat ungkapan hormat (penghargaan) positif untuk lansia dengan 
DM, dorongan maju atau persetujuan dengan gagasan atau perasaan individu dan perbadingan positif lansia dengan orang lain, seperti misalnya orang-orang yang kurang mampu atau lebih buruk keadaannya dari dirinya sendiri (menambah penghargaan diri).

\section{c. Hubungan Dukungan Instrumental terhadap self care}

Hasil uji statistik pada hubungan antara dukungan instrumental dengan selfcare menunjukkan terdapat hubungan yang erat dan $\operatorname{postif}(p$ value: 0,001$)$ antara dukungan emosional dengan selfcare.Dukungan instrumental merupakan dukungan yang diberikan oleh keluarga secara langsung yang meliputi bantuan material seperti memberikan tempat tinggal, meminjamkan uang dan bantuan dalam mengerjakan tugas rumah sehari-hari (Sarafino,2011).

\section{d. Hubungan yang paling kuat terhadap self-care}

Berdasarkan hasil analisis multivariat dengan regresi logistik ganda maka variabel yang paling dominan dan erat kaitannya dengan Self-Care adalah Dukungan emosional. Berdasarkan nilai korelasi yang paling kuat hubungannya dengan self-care klien DM tipe 2 adalah Dukungan Emosional Keluarga (Coefficients Beta (Exp (B)) = 10,875). Dukungan emosional yang diberikan keluarga kepada lansia dengan DM akan mendorong lansia tersebut untuk dapat menjalani perawatan secara teratur, hal ini dikarenakan dukungan yang diberikan tersebut dijadikan sebagai energi penggerak bagi penderita dalam menjalankan suatu program terapi dan dapat melakukan self-care dengan baik.

Pasien yang sedang berada pada masa penyembuhan akan lebih cepat sembuh apabila memiliki keluarga yang bersedia menolong (Baron \& Bryne 1994). Dukungan emosional keluarga yang ditunjukkan melalui ungkapan rasa simpati, pemberian perhatian, kasih sayng, penghargaan serta kebersamaan akan membuat lansia dengan DM merasa tenang dalam menghadapi berbagai keadaan tidak menyenangkan.

$\begin{array}{cccc}\text { Hal ini sejalan } & \text { dengan } \\ \text { penelitianliliyanti } & \mathrm{M}, \quad \mathrm{dkk}(2017) & \text { dengan }\end{array}$

menggunakan analisis pearson chisquaremenunjukkan terdapat hubungan antara dukungan emosional keluarga dengan penerimaan diri pada lansia dengan nilai $\mathrm{p}$ value $=0,001$. House 1994 dalam (setiadi,2008) juga menjelaskan bahwa lansia merasa dirinya tidak menanggung beban sendiri tetapi ada orang lain yang yang memperhatikan, mendengar, dan membantu memecahkan masalah yang terjadi.

\section{KESIMPULAN}

Distribusi karakteristik klien DM tipe 2 di Puskesmas Wara Selatan Kota Palopo adalah rerata usia pertengahan (45-59 tahun), didominasi jenis kelamin perempuan, dengan pendapatan klien sebagian besar adalah rendah, dan rata-rata lama menderita DM adalah 4-5 tahun. Ada hubungan yang signifikan antara dukungan keluarga terhadap self-care lansia dengan DM.

\section{REFERENSI}

Alligood, M.R \& Tomey, A.M. (2006). Nursing theory : uilizaion \& application. 3 ed. Missouri : Mosby.

American Diabetes Association. (2017). Standards of Medical Care in Diabetes. Vol 40. USA : ADA. Diakses pada tanggal 25 Desember 2018.

Black, M. J \& Hawks, H. J. (2009). Medical surgical nursing : clinical management for continuity of care, 8th ed. Philadephia : W.B. Saunders Company.

Departemen Kesehatan RI. 2008. Riset Kesehatan Dasar 2018. Litbangkes Departemen Kesehatan RI. Jakarta.

Depkes (2017). Tekan Angka Kematian Melalui Program Indonesia Sehat Dengan Pendekatan Keluarga. http://www.depkes.go.id/pdf.php?id=1706160 $\underline{0003}$ diakses tanggal 19 Desember 2018.

Dinas Kesehatan Kota Palopo. 2017. Profil

Kesehatan Kota Palopo. https://www.kemkes.go.id/resources/downl oad/profil/PROFIL KAB KOTA 2017/7373 S ulsel Kota Palopo 2017.pdf diakses 19 desember 2018. 
Dinkes Provinsi Sulawesi Selatan. 2015. Profil Kesehatan Provinsi Sulawesi Selatan. http://www.depkes.go.id/resources/download/ profil/PROFIL_KES_PROVINSI_2015/27_S ulsel_2015.pdf diakses tanggal 20 desember 2018.

Friedman, M. M., Bowden, V. R., \& Jones, E. G. (2010). Buku ajar keperawatan keluarga:
Riset, Teori dan Praktek. Jakarta: EGC, 5-6.

IDF. (2014). IDF Diabetes Atlas,

http://www.idf.org diakses pada tanggal 20 Desember 2018.

PERKENI. (2015). Konsesus Pengelolaan dan Pencegahan Diabetes Melitus Tipe 2 di Indonesia. Perkumpulan Endokrinologi Indonesia. 